\title{
Evaluation of Pulmonary Function in Goats Affected with Bacterial Pneumonia
}

\author{
Trupti S. Kattimani*, B. G. Ravindra, T. Vinay, K. Shrikant, R. K. Vivek and N. A. Patil \\ Department of Veterinary Medicine, Veterinary College, Bidar, Karnataka, India
}

*Corresponding author

\begin{tabular}{|c|}
\hline Keywords \\
\hline $\begin{array}{l}\text { Goats, Bacterial } \\
\text { pneumonia and } \\
\text { pulmonary function }\end{array}$ \\
\hline Article Info \\
\hline $\begin{array}{l}\text { Accepted: } \\
15 \text { December } 2019 \\
\text { Available Online: } \\
20 \text { January } 2020\end{array}$ \\
\hline
\end{tabular}

\section{A B S T R A C T}

\section{Introduction}

In India, goat rearing is one of socio economic status to low and moderate farmers. The goats are low cost with highly profitable, adoptable, small in size and easy to handle so in traditional goats are referred as "poor man's cow". In the present situation intensive goat farming system affect the health of goats due to overcrowding, transport stress, immunity and sudden change in the environmental condition that precipitates respiratory problems in goats causing severe economic loss to the farmer. Among this pneumonia is a major problem and pose threat in goat farming. So the current study was envisaged to know the incidence of bacterial pneumonia and any changes in pulmonary function by different diagnostic methods such as hematology, blood gas analysis and radiographic study and also aids in assessing the severity and prognosis of bacterial pneumonia in goats. 


\section{Materials and Methods}

\section{Incidence of bacterial pneumonia}

The incidence of bacterial pneumonia in goats was studied from August 2016 to July 2017. During theis period, naturally infected clinical cases of bacterial pneumonia in goats presented to Veterinary Clinical Complex (VCC), Veterinary College Bidar was undertaken for detailed clinical, physical and physiological examination with supportive diagnostic aids such as pulmonary function score, isolation and identification, haematologyy, blood gas analysis and radiographic study.

\section{Clinical examination}

To assess the pulmonary function of bacterial pneumonia in goats, the detailed examination of suspected cases was performed as per the pulmonary function score card by clinical assessment and physical examination (table1)

\section{Isolation and identification of bacteria}

Isolation and identification of the bacterial origin is followed as per standard protocol.

\section{Hematological examination}

The two $\mathrm{ml}$ of whole blood was collected in K2 EDTA- 2ml, J. K. diagnostics vials from jugular vein for haematological investigations. Total erythrocyte count (TEC), Total leukocyte count (TLC), Packed cell volume (PCV), Haemoglobin content $(\mathrm{Hb})$, Mean corpuscular volume (MCV), Mean corpuscular haemoglobin (MCH), Mean corpuscular haemoglobin concentrations (MCHC) in automatic blood cell counter (ERMA INC) and Differential leucocytic count (DLC) was done with Giemsa staining technique as per standard methods (Sadeghiana et al., 2011 and Ghanem et al.,
2015) to know any alterations in hematological value implicating bacterial pneumonia in comparison with the normal healthy goats.

\section{Blood gas analysis}

Similarly two ml venous blood was collected, on the day of case presentation and immediately run into the blood gas analyzer. The blood gases were analyzed to assess the pulmonary function by recording the changes in venous partial pressure of carbon dioxide $\left(\mathrm{VpCO}_{2}\right)$, venous partial pressure of oxygen $\left(\mathrm{VpO}_{2}\right)$, venous Actual bicarbonate ion $\left(\mathrm{VHCO}_{3} \mathrm{~A}\right)$, venous total carbon dioxide content $\left(\mathrm{VtCO}_{2}\right)$ venous base excess (VBE), venous hydrogen ion concentration $\left(\mathrm{VH}^{+}\right)$and venous oxygen saturation $\left(\mathrm{VO}_{2}\right.$ sat) and compared with the normal healthy goats.

\section{Radiography}

To assess the different pulmonary function scores in pneumonic goats, the radiography was taken to confirm the pneumonia (Smith and Sherman, 2009). On the day of case presentation the X-ray of thoracic region was taken out during inspiratory pause with $\mathrm{kVp}$ 55 and mAs 6. On radiographic examination infiltration, density and contrast of chest $\mathrm{X}$ ray were recorded to assess the pneumonic condition. The severity of pneumonia was scored as mild (score 1), moderate (score 2) and severe (score 3) cases, which was compared with the normal chest radiography of healthy goats.

\section{Statistical analysis}

The haematological and blood gas values obtained were analyzed by ANOVA using SPSS (statistical package for social sciences) version20. The results were demonstrated as means \pm SE. The results were considered statistical significant when $\mathrm{p}<0.05$. 


\section{Results and Discussion}

In this prospective study a total of 117 pneumonic goats were screened, of which 24 goats suffering from bacterial pneumonia were evaluated in detail to assess the pulmonary function as follows.

\section{Clinical signs}

The clinical signs in goats affected with bacterial pneumonia were recorded (FIG.1 ) as pyrexia, sneezing and coughing were found to be 100 per cent followed by congestion of mucous membrane $(95.83 \%)$, bilateral nasal discharge (91.66\%), tachypnoea (91.67\%), dyspnoea $(87.50 \%)$, tachycardia $(79.17 \%)$, ocular discharge $(75.00 \%)$, anorexia $(75 \%)$, mucopurulent nasal discharge $(66.67 \%)$ and crackles sound on lung auscultation $(58.33 \%)$ were considered as major indicator markers in identification of bacterial pneumonia in goats. The results were in agreement with, Ghanem et al., (2015) and Chung et al., (2015) in pneumonic goats.

The goats were examined in detail for assessing the pulmonary function scoring. Among twenty-four cases of bacterial pneumonia in goats, 15 goats were scored as score 3 i.e. severe infected followed by 8 goats were scored as score 2 i.e. moderately infected and 1 goat scored as score 1 which was mild infected (plate 1). The similar scoring was done by Christodoulopoulos et al., (2002) in lambs. In pneumonic goats to assess the pulmonary function along with that prognosis of disease condition can be elucidated.

\section{Isolation and identification of bacterial origin in pneumonic goats}

From the infected goats the bacteria isolated from the nasal swabs were Pasteurella spp. (20.83\%) followed by Mannheimia spp.
(16.67\%) cent, Pseudomonas spp. (12.50\%), Escherichia spp. (12.50\%), Staphylococcus spp. (12.50\%), Bacillus spp. (8.33\%) and mixed infection (16.67\%). (FIG 2, Plates 2, 3, $4,5,6,7)$ The results revealed that Pasteurella spp. and Mannheimia spp. were found to be most predominant and pathogenic. The comparable results were observed by earlier workers, Hussein et al., (2006) Momin et al., (2011)

\section{Haematological parameters}

The detailed hematological changes in bacterial pneumonia of goats showed in table.2. The results revealed that significant changes $(\mathrm{P}<0.05)$ in Leucocytic count with neutrophilia and lymphopaenia when compared to healthy goats in the present study may be attributed to acute inflammatory changes in lower respiratory tract particularly due to bacterial infection in pneumonic goats. The present results agreed with Nahed and Tamer (2014) in ewes, Ghanem et al., (2015) in Boer goats, The stress induced during respiratory illness that result in endogenous release of corticosteroids, which have a major role in regulating the concentration of leucocytes in mild to severe pneumonia in goats. However other parameters such as monocytic count, MCHC and PCV found to be significantly altered but they are all within normal physiological range and rest of the parameters were found to be non significant.

\section{Blood gas analysis}

The blood gas values of goats shown in table2 revealed that there was significant elevation $(\mathrm{P}<0.05)$ in the $\mathrm{VpCO} 2, \mathrm{VtCO}_{2}$ and $\mathrm{H}^{+}$ions, while significant decrease $(\mathrm{P}<0.05)$ in $\mathrm{VpO}_{2}$ and $\mathrm{VO}_{2}$ sat values may be due to respiratory acidosis leading to pulmonary hypoventilation and hypoxic condition in bacterial pneumonia. The results were in accordance with Ghanem et al., (2015) 
Table.1 Pulmonary function score card for pneumonic goats

\begin{tabular}{|c|c|c|c|c|c|}
\hline Sl. No & Score Parameters & Score 0 & Score 1 & Score 2 & Score 3 \\
\hline 1 & Rectal temperature & Normal & Elevated & High & Very High \\
\hline 2 & $\begin{array}{l}\text { Conjunctival mucous } \\
\text { membrane }\end{array}$ & Pink & Congested & Congested & Severe Congested \\
\hline 3 & Respiratory rates & Normal & Tachypnoea & Dyspnoea & High dyspnoea \\
\hline 4 & Heart rates & Normal & High & Tachycardia & Tachycardia \\
\hline 5 & Lung auscultation & $\begin{array}{l}\text { No } \\
\text { abnormal } \\
\text { sound }\end{array}$ & $\begin{array}{l}\text { Moist rales on } \\
\text { anterior lung }\end{array}$ & $\begin{array}{l}\text { Moist rales on } \\
\text { whole lung }\end{array}$ & $\begin{array}{l}\text { Crepitant sound } \\
\text { on whole lung }\end{array}$ \\
\hline \multirow[t]{3}{*}{6} & Nasal discharge & No & Present & Present & severe \\
\hline & Unilateral/ bilateral nares & No & Unilateral & Bilateral & Bilateral \\
\hline & $\begin{array}{l}\text { b) serous/mucous/ } \\
\text { mucopurulent }\end{array}$ & No & Serous & Mucous & Mucopurulent \\
\hline 7 & Ocular discharge & No & Scanty, serous & Serous to mucous & Mucous to purulent \\
\hline 8 & Sneezing & No & Slightly & Present & Severe \\
\hline 9 & Coughing & No & Slightly & Present & Severe \\
\hline 10 & Feed intake & Normal & Reduced & Inappetence & Anorexia \\
\hline
\end{tabular}

Table.2 Comparative evaluation hematological and blood gas parameters of bacterial pneumonia in goats

\begin{tabular}{|l|l|l|}
\hline PARAMETERS (Units) & Healthy goats $(\mathbf{N}=6)$ & Diseased goats $(\mathbf{N}=\mathbf{2 4})$ \\
\hline $\mathrm{WBC}\left(10^{3} / \mu \mathrm{l}\right)$ & $10.92 \pm 1.08$ & $18.74 \pm 1.09^{*}$ \\
\hline $\mathrm{RBC}\left(10^{6} / \mu \mathrm{l}\right)$ & $14.92 \pm 0.15$ & $13.34 \pm 0.70$ \\
\hline $\mathrm{HB}(\mathrm{g} / \mathrm{dl})$ & $9.13 \pm 0.34$ & $8.65 \pm 0.51$ \\
\hline $\mathrm{PCV}(\%)$ & $23.43 \pm 0.75$ & $28.41 \pm 0.20^{*}$ \\
\hline $\mathrm{MCV}(\mathrm{fl})$ & $15.62 \pm 0.36$ & $19.06 \pm 1.46$ \\
\hline $\mathrm{MCH}(\mathrm{pg})$ & $6.05 \pm 0.19$ & $5.80 \pm 0.46$ \\
\hline $\mathrm{MCHC}(\mathrm{g} / \mathrm{dl})$ & $38.83 \pm 0.48$ & $32.95 \pm 2.05^{*}$ \\
\hline NEUTROPHIL $(\%)$ & $40.83 \pm 1.30$ & $54.00 \pm 1.10^{*}$ \\
\hline ESIOPHILS(\%) & $1.50 \pm 0.51$ & $0.96 \pm 0.32$ \\
\hline $\mathrm{LYMPHOCYTE}(\%)$ & $56.67 \pm 1.36$ & $42.04 \pm 1.17^{*}$ \\
\hline $\mathrm{MONOCYTE}(\%)$ & $0.67 \pm 0.37$ & $2.63 \pm 0.14^{*}$ \\
\hline $\mathrm{BASOPHILS}(\%)$ & $0.33 \pm 0.24$ & $0.33 \pm 0.07$ \\
\hline $\mathrm{VpCO}_{2}(\mathrm{mmHg})$ & $36.70 \pm 6.59$ & $54.71 \pm 3.10^{*}$ \\
\hline $\mathrm{VpO}_{2}(\mathrm{mmHg})$ & $95.13 \pm 11.62$ & $68.23 \pm 4.67^{*}$ \\
\hline $\mathrm{VHCO}_{3} \mathrm{~A}(\mathrm{mmol} / \mathrm{l})$ & $17.87 \pm 0.95$ & $20.67 \pm 0.12$ \\
\hline $\mathrm{VtCO}_{2}(\mathrm{mmol} / \mathrm{l})$ & $18.02 \pm 1.86$ & $23.48 \pm 1.19^{*}$ \\
\hline $\mathrm{VH}^{+}(\mathrm{nmol} / \mathrm{l})$ & $53.28 \pm 6.47$ & $76.37 \pm 7.03^{*}$ \\
\hline $\mathrm{VBE}^{*}(\mathrm{mmol} / \mathrm{l})$ & $-4.06 \pm 0.36$ & $-4.66 \pm 0.69$ \\
\hline $\mathrm{VO}_{2} \mathrm{SAT}(\%)$ & $88.58 \pm 2.50$ & $68.84 \pm 3.46^{*}$ \\
\hline
\end{tabular}

Mean \pm SE across a column with $(*)$ superscripts differ significantly $(\mathrm{P}<0.05)$ 
Int.J.Curr.Microbiol.App.Sci (2020) 9(1): 1044-1053

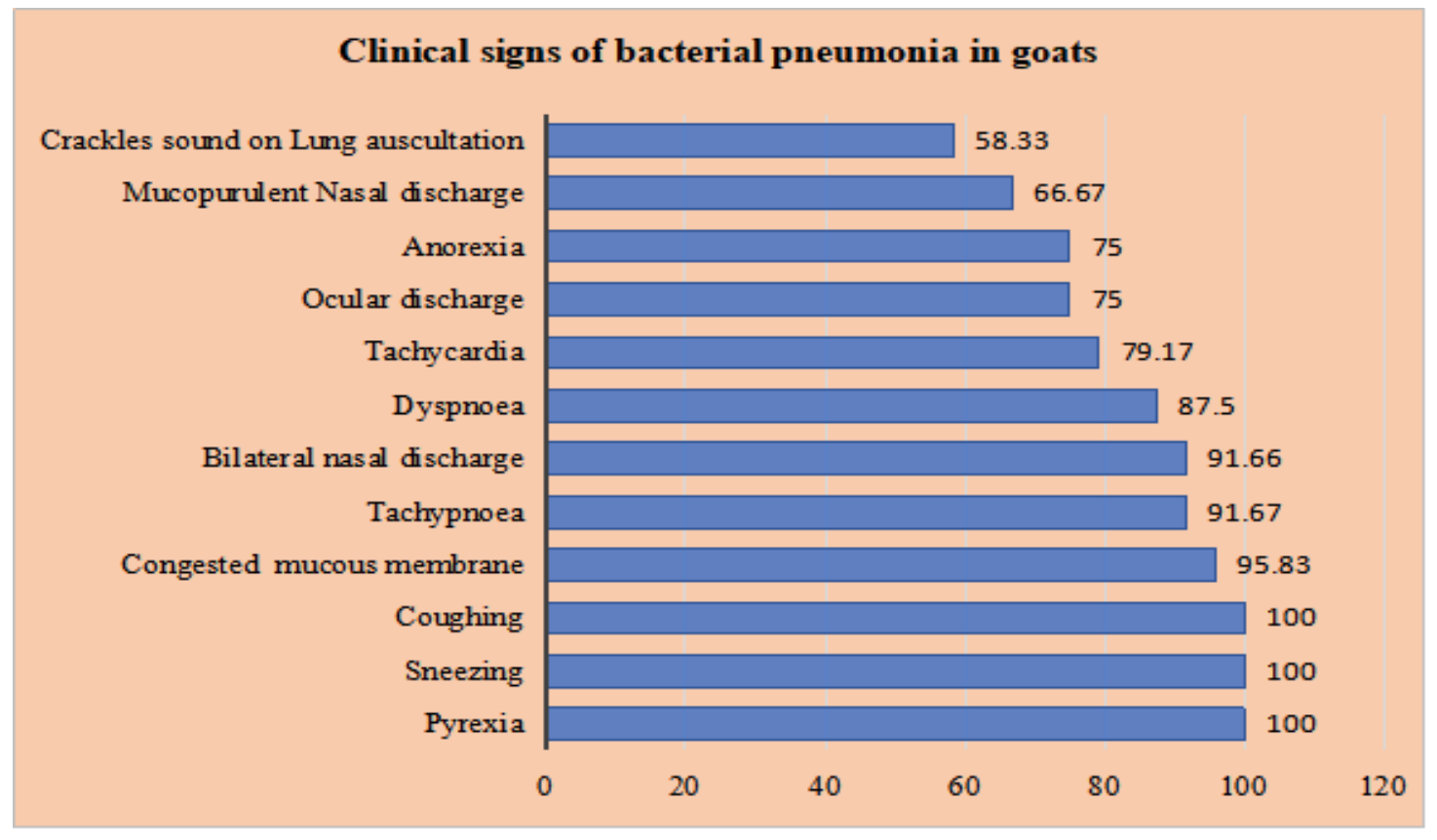

Fig.1 Predominant clinical signs observed in bacterial pneumonia in goats

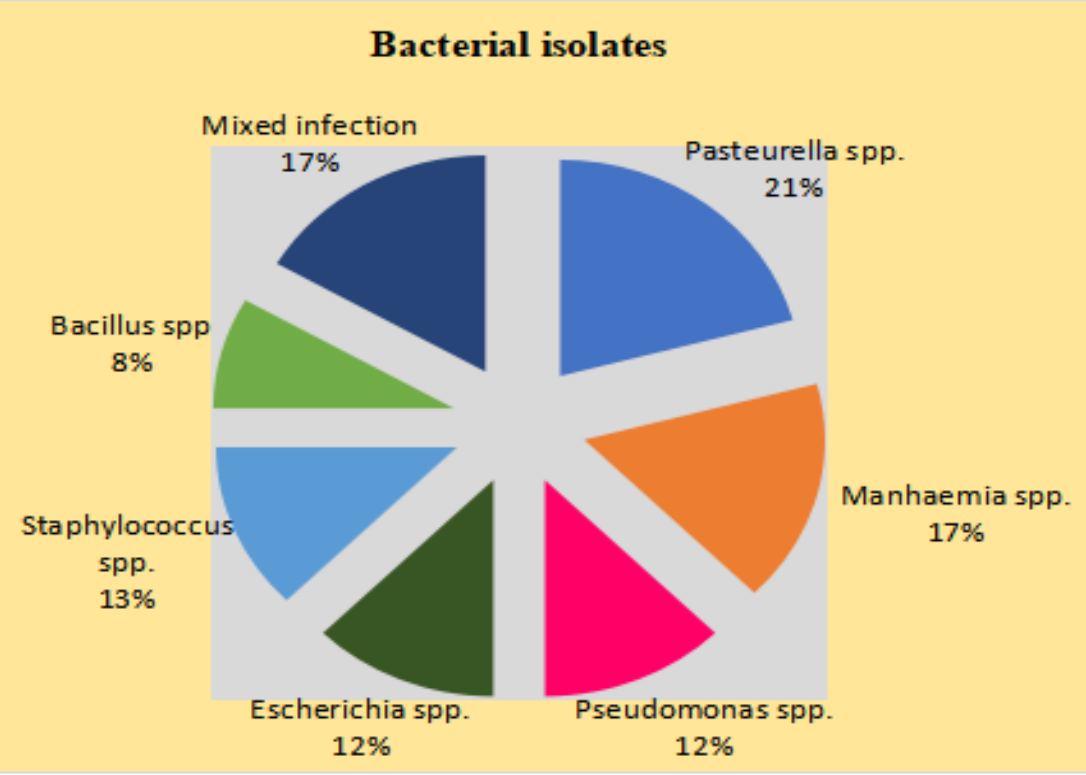

Fig.2 Bacterial isolate of pneumonic goats 


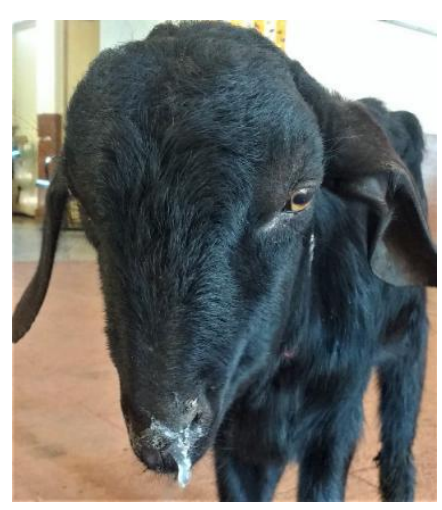

Score 1

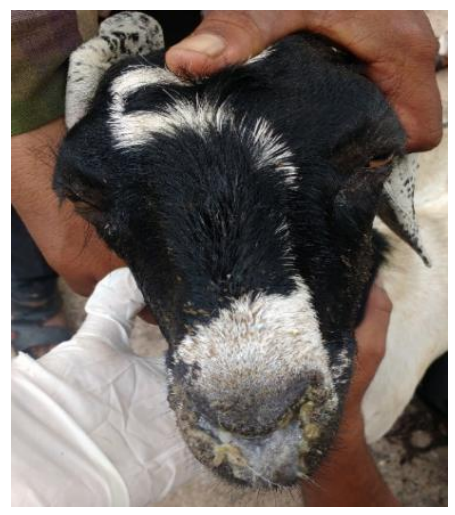

score 2

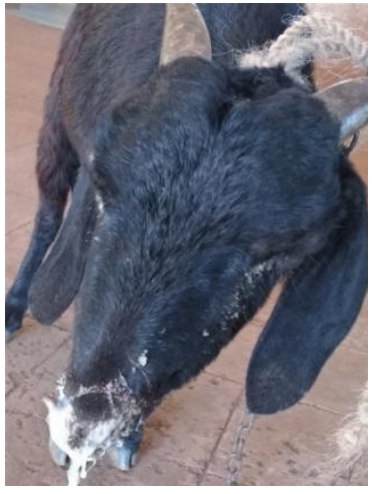

score 3

Plate.1 The pneumonic goats showing serous to mucopurulent nasal and ocular discharge
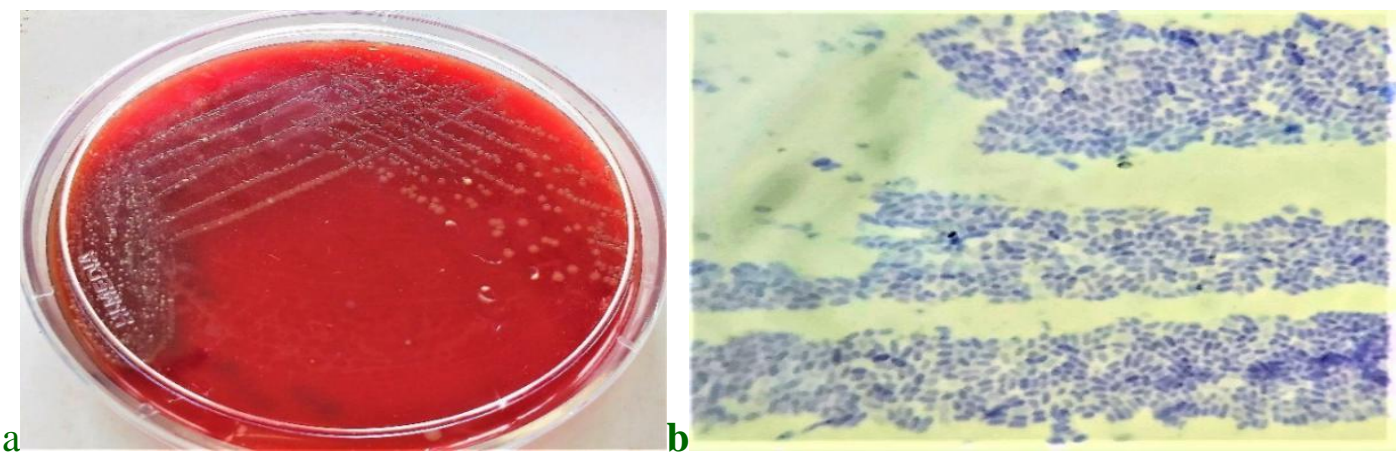

Plate.2 a: $\quad$ Pasteurella spp. showed the gray dew drop colony with fruity odour, nonhaemolytic colony in sheep blood agar; b: Pasteurella spp. showed the bipolar organism in Methylene blue stain
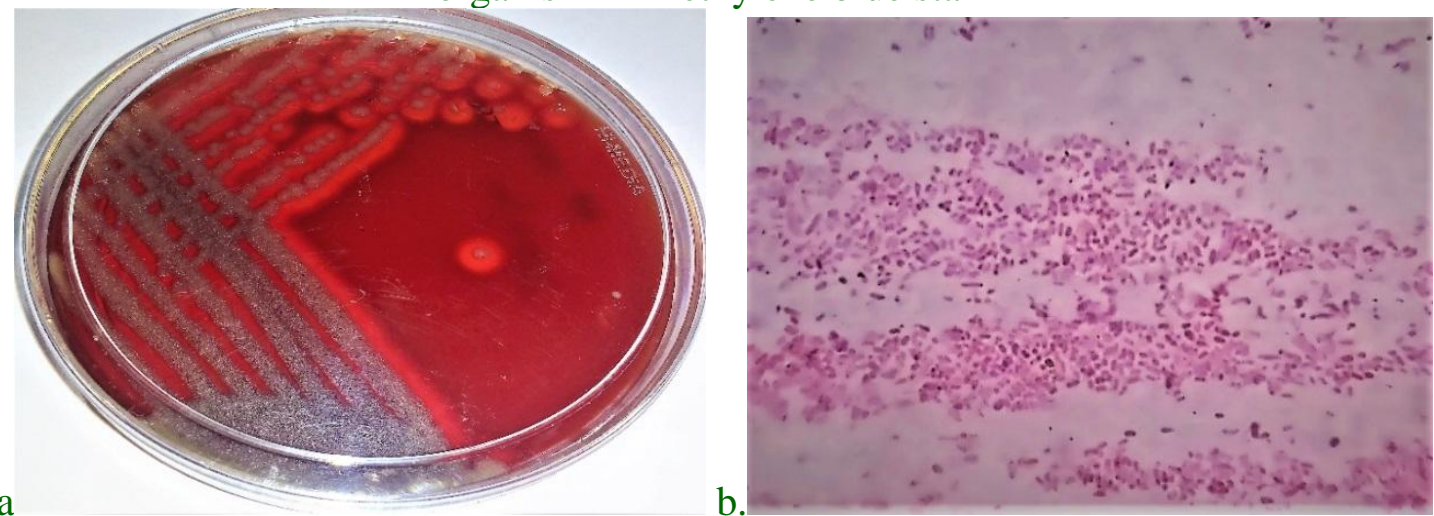

Plate.3 a: Mannheimia spp. showed small, dew drop greyish, complete haemolysis in sheep blood agar; B:Mannheimia spp. bacteria showed the gram-negative coccobacilli in Gram's stain 
a.
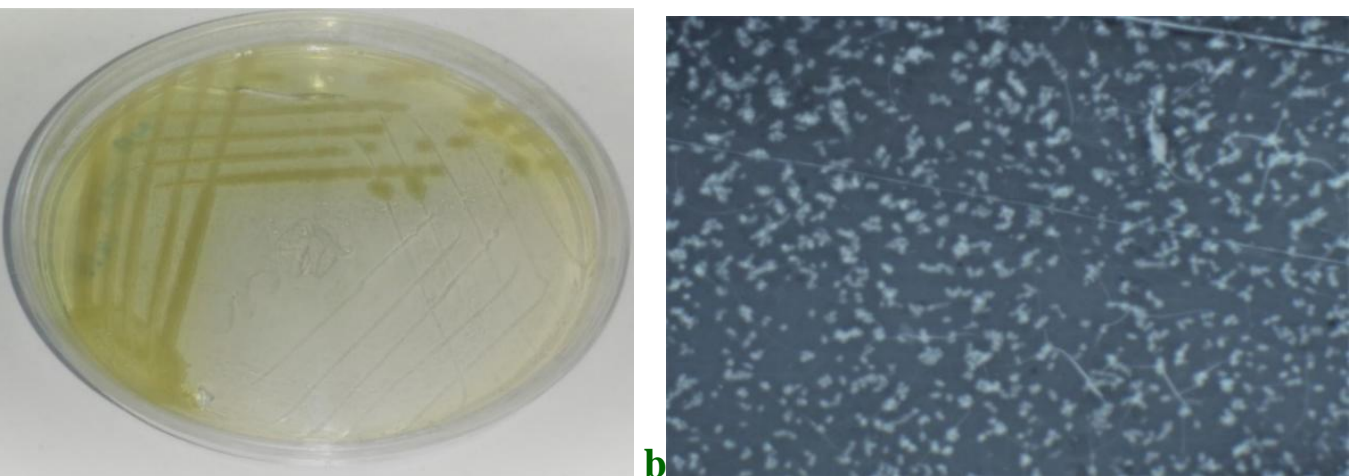

Plate.4 a: Pseudomonas spp. showing the greenish pigmentation with fried egg appearance colonies in nutrient agar.

b:Pseudomonas spp. in negative staining ,observed hollow organism white capsule in black background
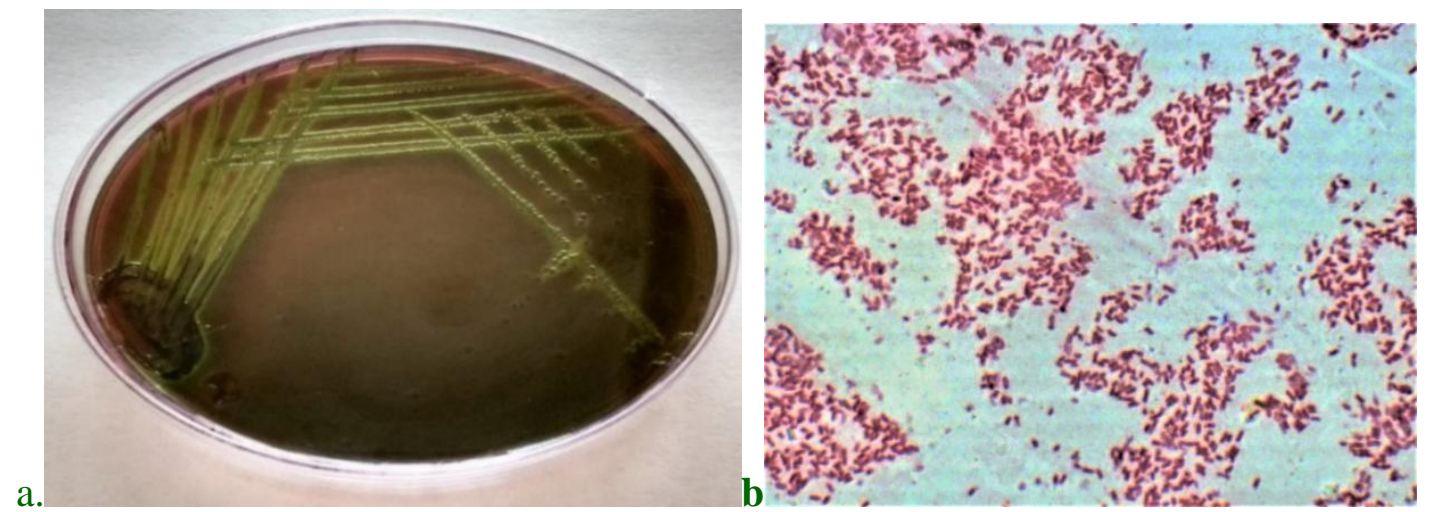

Plate.5 a: Escherichia spp. showing metallic sheen growth in Eosin methylene blue agar. b: Escherichia spp. showing in Gram's staining, gram-negative, non-spore forming rods, single or paired observed
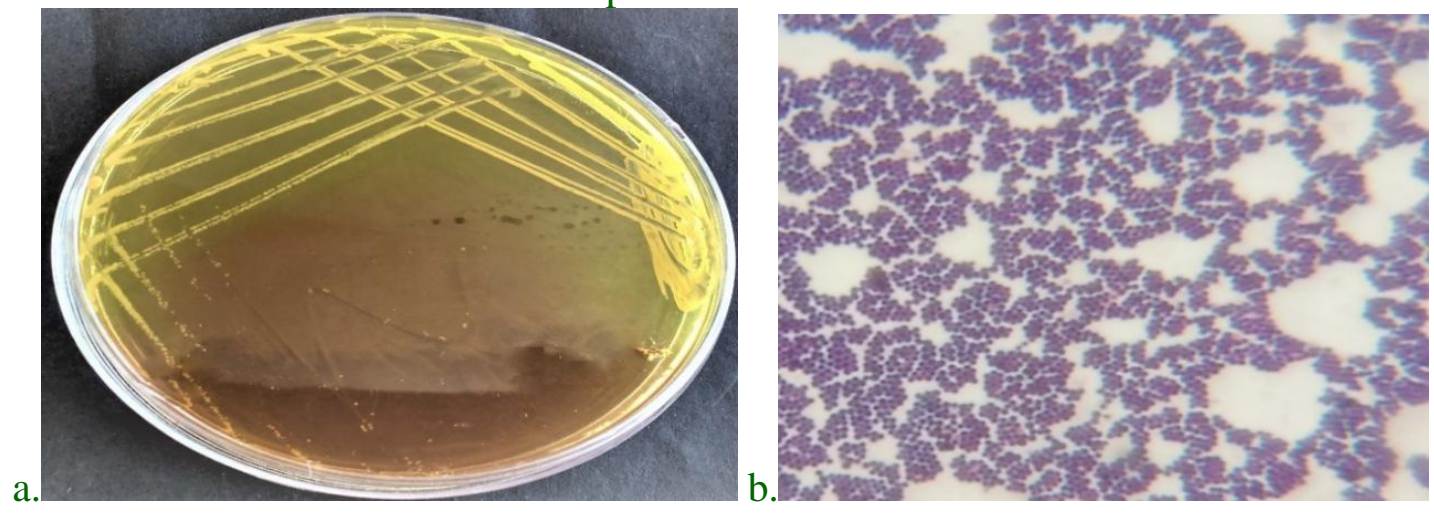

Plate.6 a: Staphylococcus spp. showed golden yellow colour colony in Mannitol salt agar. b: Staphylococcus spp. showing gram-positive cocci arranged in grape like clusters in Gram's stain 
A.
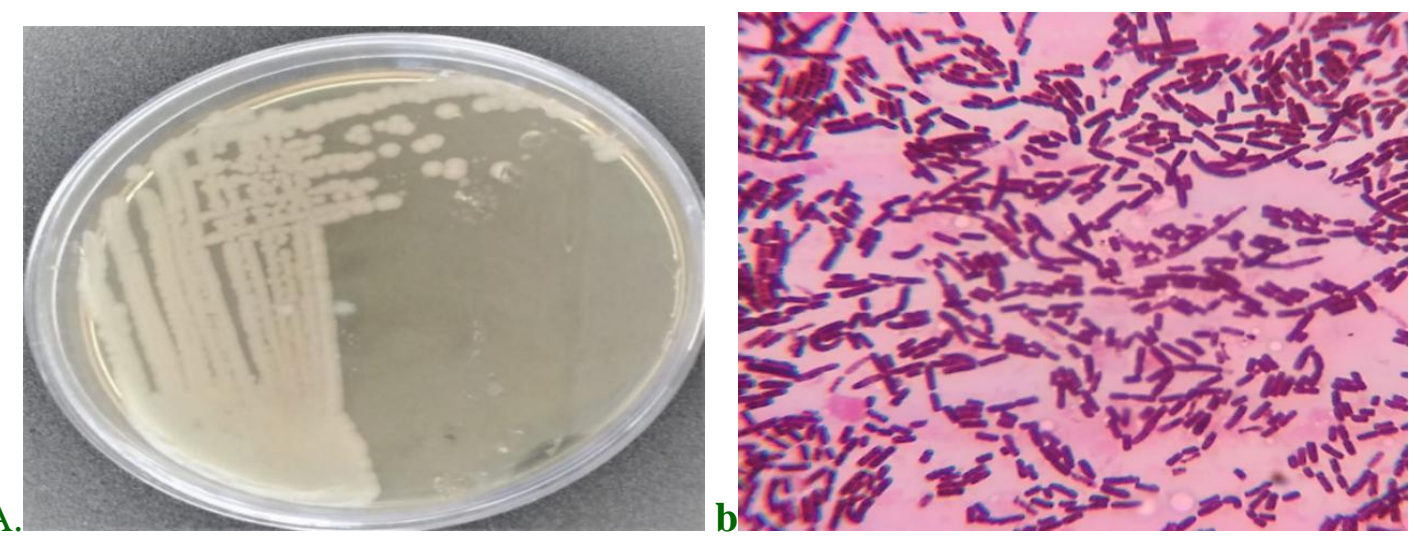

Plate.7 a: Bacillus spp. showing irregular, round, opaque, dull, grayish white colony in nutrient agar; b: Bacillus spp. showing in gram positive, single or pair in chain of bacilli seen in the Gram's stain
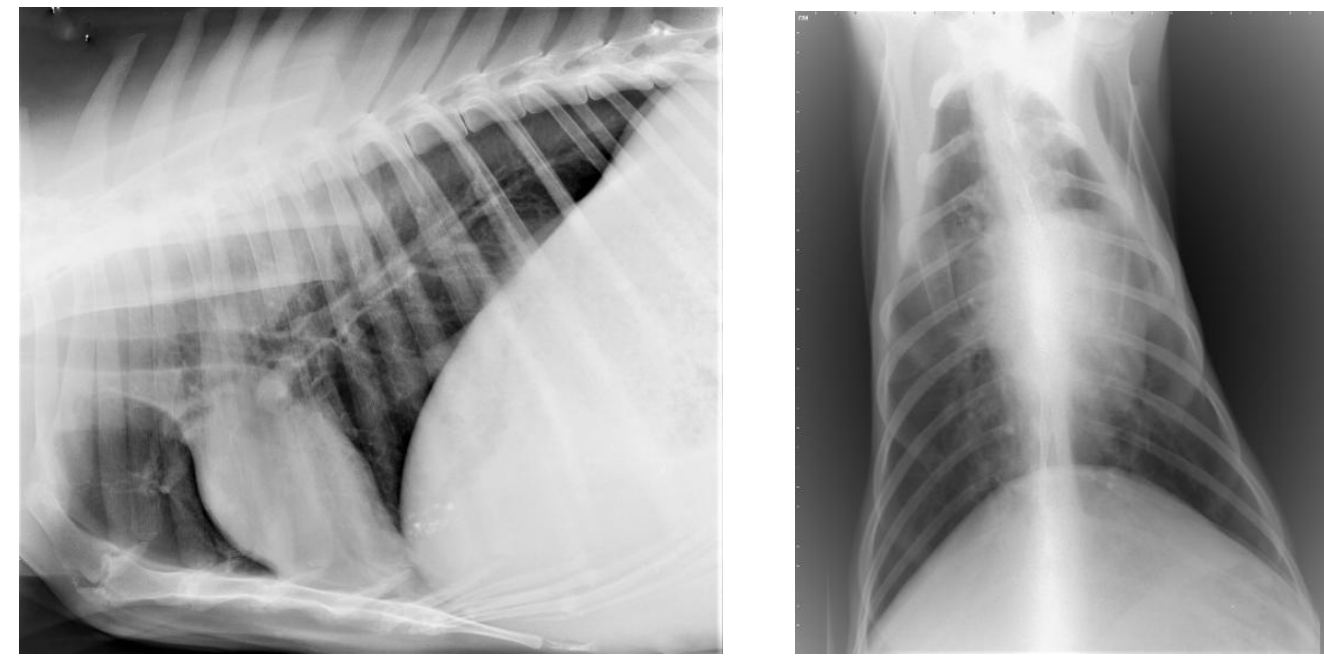

Plate.8 Thoracic radiography of goat showing normal lung (score 0)
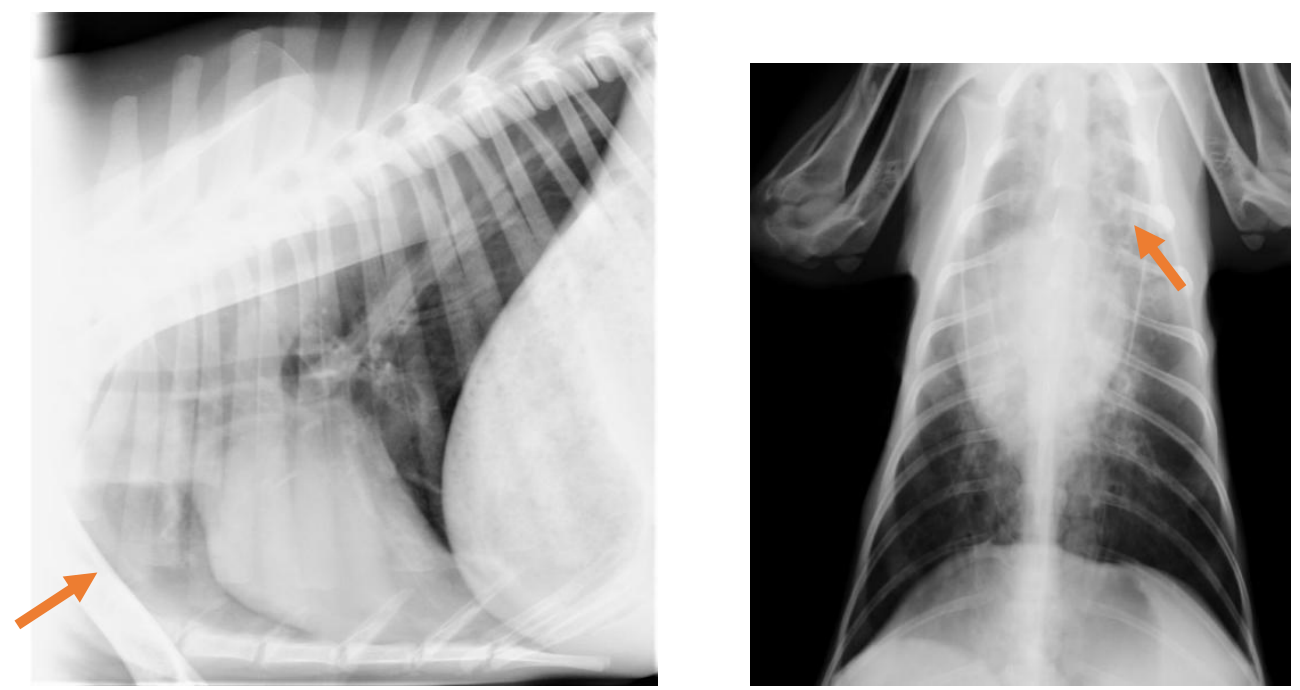

Plate.9 Thoracic radiography of lung showing mild pneumonic changes in goat (score 1) 


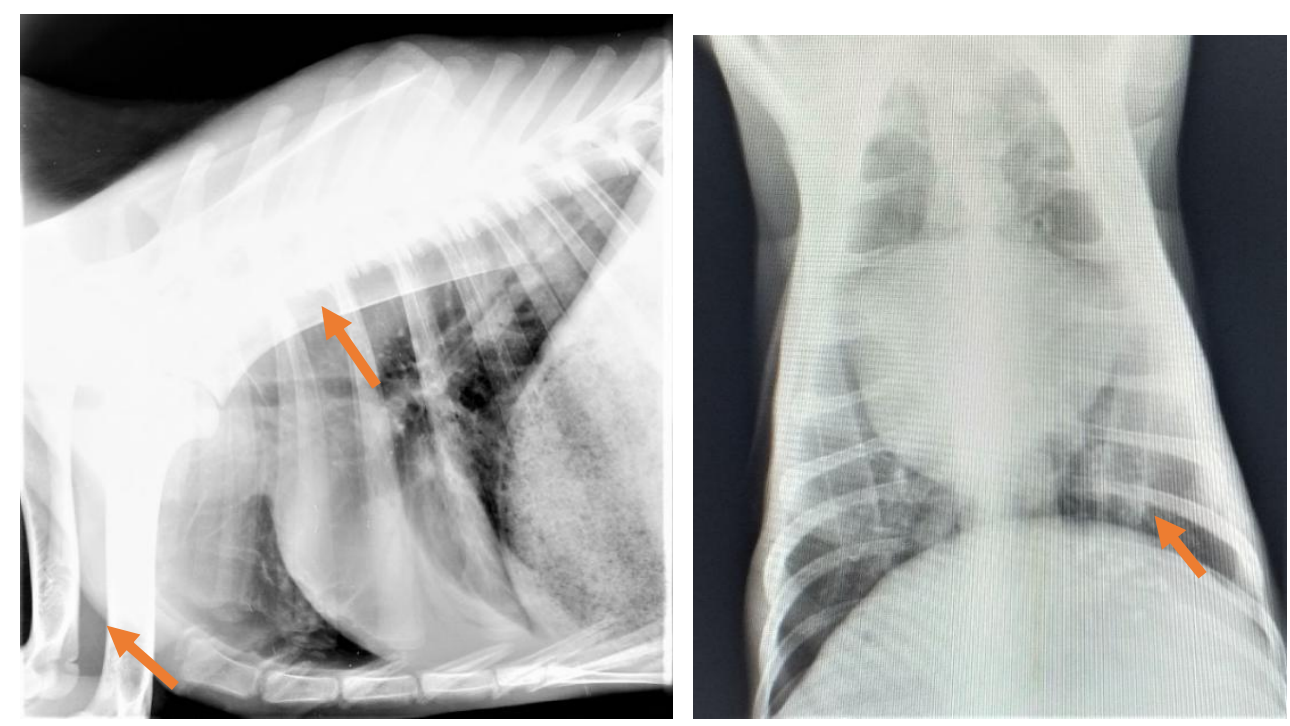

Plate.10 Thoracic radiography of lung showing moderate pneumonic changes in goat (score 2)
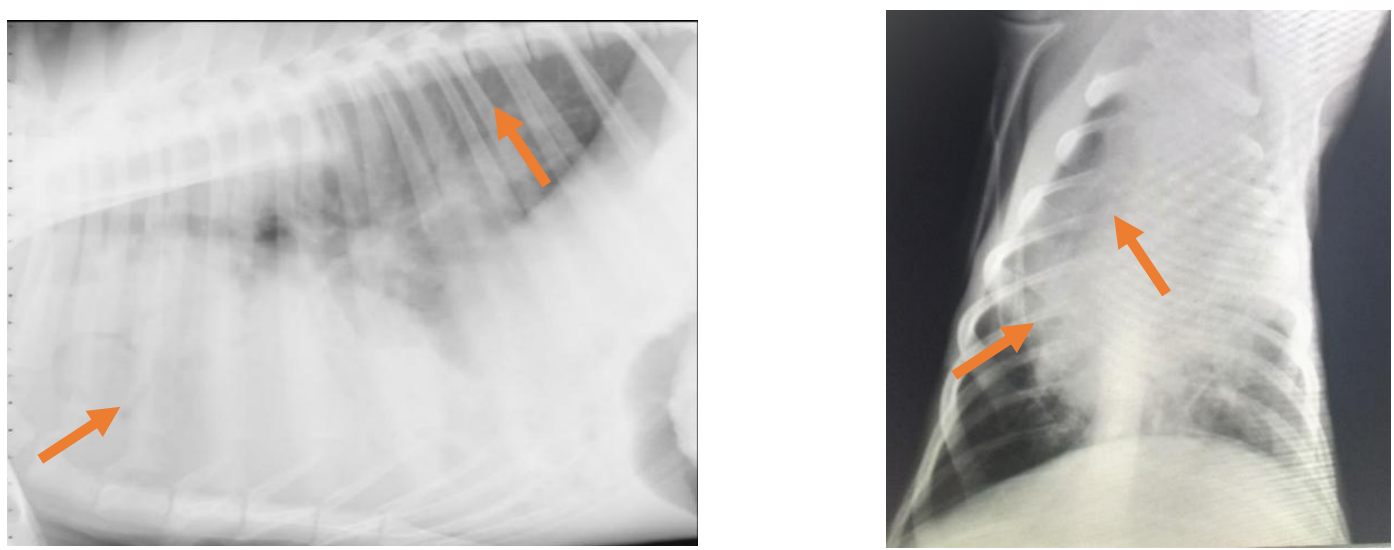

Plate.11 Thoracic radiography of lung showing severe pneumonic changes in goat (score 3)

\section{Radiographical study}

Radiography is thought to be one of the 'gold standard test' for confirmation of pneumonia in goats (Bossuyt et al., 2007). Masseau et al., (2008) opined that radiography study was 94 per cent sensitive for detecting the lower respiratory tract infection in cattle. Therefore in the present study both infected and healthy goats were subjected to radiographic examination. Based on the radiographic examination severity of bacterial pneumonia in goats were confirmed and scored as score1,2 and 3 by observing infiltration density, contrast and areas of lung affected when compared to healthy goats (Plate 8,9,10,11).
The results were in agreement with Falcon et al., (1985). Extensive changes observed in the lungs on radiographic examination may help in assessing the severity and also prognosis of the condition (Smith and Sherman, 2009).

Hence concluded that the present study suggested the Pulmonary function in goats affected with bacterial pneumonia may be effectively diagnosed by employing different diagnostic methods such as hematology, blood gas analysis and radiographic study in supportive with detailed clinical examination aids in assessing the severity and prognosis of bacterial pneumonia in goats. 


\section{Acknowledgement}

The authors are highly thankful to Veterinary College, KVAFSU Bidar for providing necessary facility to undertake the research work and also to farmers who extended their co-operation for carrying out this work.

\section{References}

Bossuyt, P. M., Reitsma, J. B., Burns, D. E., Gatsonis, C. A., Glaszious, P. P. and Irwig, L.M., 2007. Towards complete and accurate reporting, studies of diagnostic accuracy: the STARD initiative. Veterinary Clinical Pathology 36 (1):8

Christodoulopoulos, G., Warnick, L. D., Papaioannou, N. and FTHENAKIS, G. C., 2002. Tilmicosin administration to young lambs with respiratory infection: safety and efficacy considerations. Jorunal of Veterinary Pharmacology and Therapeutics., 25: 393-397.

Chung, E. L. T., Abdullah, F. F. J., Abba, Y., Tijjani, A., Sadiq, M. A., Mohammed, K., Osman, A. Y., Adamu, L., Lila, M. A. M. and Haron, A. W., 2015. Clinical management of pneumonic pasteurellosis in Boer kids: A case report. International Journal Of Livestock Research, 5(4): 100-104.

Falcon, J., Smith, B. P., O'brien, T. R., Carlson, G. P. and Biberstein, E., 1985. Clinical and radiographic findings in Corynebacterium equi pneumonia of foals. Journal of the American Veterinary Medical Association, 186 (6): 593-599.

Ghanem, M. M., Yousif, H. M., EL-Ghany, A. H., EL-Raof, Y. M. and Elattar, H. M.,
2015. Evaluation of pulmonary function tests with hemato-biochemical alterations in Boer goats affected with Klebsiella pneumoniae. Benha Veterinary Medical Journal, 29(1): 53-62.

Hussein, E. A., Alam, T. and Masoud, E. A., 2006. Some studies on clinical, haematological and biochemical changes in pneumonic lambs with trials of treatment. Mansoura Journal of Veterinary Medicine, 8: 81-97.

Masseau, I., Fecteau, G., Breton, L., Hélie, P., Beauregard, G. and Blond, L., 2008. Radiographic detection of thoracic lesions in adult cows: A retrospective study of 42 cases (1995-2002). Canadian Veterinary Journal, 49: 261-267.

Momin, M. A., Islam, M. A., Khatun, M. M., Rahman, M. M. and Islam. M. A., 2011. Characterization of bacteria associated with pneumonia in black Bengal goats. Bangladesh Journal of Veterinary Medicine, 9(1): $67-71$.

Nahed, S. S. and Tamer, S. A. 2014. Pneumonia in sheep: bacteriological and clinicopathological studies. American Journal of Research Communication, 2(11): 73-88.

Sadeghiana, S., Mohammad, R. M. D., Gholam, A. K., Taghi T. B. and Abbas, T., 2011. Pasteurella multocida pneumonic infection in goat: hematological, biochemical, clinical and pathological studies. Small Ruminant Research, 100: 189- 194.

Smith, C. and Sherman, D., 2009. Respiratory system. In: Goat medicine. Edn.2 ${ }^{\text {nd }} . A$ John Wiley \& Sons, Inc., Publication. pp: 339-376.

\section{How to cite this article:}

Trupti S. Kattimani*, B. G. Ravindra, T. Vinay, K. Shrikant, R. K. Vivek and N. A. Patil. 2020. Evaluation of Pulmonary Function in Goats Affected with Bacterial Pneumonia. Int.J.Curr.Microbiol.App.Sci. 9(01): 1044-1053. doi: https://doi.org/10.20546/ijcmas.2020.901.117 